\title{
THE PHENOMENON OF COLLECTIVE SECURITY AS AN ELEMENT OF INTERNATIONAL SECURITY IN THE SYSTEM OF INTERNATIONAL RELATIONS
}

\begin{abstract}
International security is a special state of international relations that reflects the degree of national interests of all actors in world politics. The foreign policy relations of states are based on their observance of generally accepted principles and norms of international law. Adherence to such norms ensures the resolution of conflicting issues and differences between them without the use of force or threat of force.

It is noted that arms control is aimed at limiting the number of weapons and regulating their use through bilateral and multilateral treaties and agreements. At the same time, disarmament is aimed at eliminating entire categories of weapons systems. It is noted that the proliferation of weapons of mass destruction poses a serious threat to international security.

The purpose of this work is to explore the role of collective security and its characteristics as an element of international security in the system of international relations. This study is based on the work of scientists who have studied at different times issues related to the system of collective security, namely: V.G. Butkevych, S.V. Riznyk, O.S. Kuchyk, I.I. Lukashuk, O.S. Vlasiuk, and others.

The article highlights the modern interpretation of the content of international security, which is characterized by certain areas, as following arms control, environmental protection, reduction and non-proliferation of weapons of mass destruction, counter-terrorism, migration flows to prevent ethno-national and religious conflicts.

It is stated that collective security prefers universal or global forces with the participation of all states, to maintain international peace and security, and therefore these measures are aimed at ensuring a stable, comprehensive peace. Accordingly, states are jointly ready to defend international peace and security by conducting joint military action against acts of aggression. The system of collective security guarantees by neutralizing by joint efforts any acts of aggression or war against the victim state.
\end{abstract}

Key words: act of aggression, world peace and security, war, collective defense, national security.

JEL Classification: K33, Z18.

\section{Liudmyla FILIANINA,}

Associate Professor at the Department of International Law

University of Customs and Finance,

PhD, Associate Professor

Filyanina.la@gmail.com

orcid.org/0000-0002-8805-5510

\section{Introduction}

International security - is specific state of international relation, which represents degree of security of national interests for all subjects of world politics. Foreign relations of states are based on their observance of generally accepted principles and norms of international rights. Observance of such norms provides solutions to controversial issues and differences between them without using of power or threats of force.

\section{Analysis of recent research and publications}

Research of some issues associated with system of implementation of collective security at the different time was studied by researchers, namely: V.G. Butkevych, O.S. Vlasiuk, O.S. Kuchyk, I.I. Lykashuk, S.V. Riznyk and others. Analysis of this and other researcher's works became scientific base for this scientific work.

The purpose of the article - to explore the role of collective security and it self's characteristics as element of international security at system of international relations.

\section{Presenting of main material}

In the last decade, geopolitical problems of implementation of international peace and security bring international relations to a new level. At the last years states are trying to develop 
mechanisms to ensure national security for creation of general approaches and effective tools that affect global security.

Interest in the problem of regulation of international (global) security is shown by all of subjects of international relation from The United Nations to non-governmental organizations and other establishments which are not integrated into international system. For example, Article 1 of the UN Charter defines main aim of organization as maintaining effective collective action to prevent and eliminate threats to peace and suppression of acts of aggression or any other violations of peace.

\subsection{Modern interpretation of the content of international security}

Modern interpretation of the content of international security is characterized by directions as following arms control, disarmament - is reducing the number of and nonproliferation of weapon of mass destruction, environmental protection, counter-terrorism, migration flows to prevent ethno-national and religious conflicts.

Arms control aimed at limiting the number of weapons and regulation of its usage through bilateral and multilateral agreements and arrangements. Such agreements complemented by international cooperation in the field of export control, due to the relevant aspect of counter-terrorism and human rights activities of the international community. As example, states of European region developed an integrated approach to build trust and security, which is reflected in The Vienna Document on Confidence- and Security-Building Measures 2011. It increases level of international security, predictability, transparency, military stability and reduces the risk of conflict in Europe; also, it promotes trust and predictability through transparency and verification measures, which cover the armed forces and main systems of arms and technique. Thus, arms control agreements often impose restrictions on testing, deploying or using certain types of weapons. Such agreements mutually oblige States parties to limited control of their weapons.

On the other side, states enter into agreements the purpose of which is reduction or elimination of armaments. Disarmament is aimed at liquidation of whole categories of weapon systems, which directly forbid possession or production of weapons. First trial of arms limitation happened at 1899 at The Hague Peace Conference, where it couldn't limit arms, but it regulated a number of territory and functional questions. Subsequently, The Land War Laws and Customs Regulations, which is an addition to the IV Convention on the Laws and Customs of War on Land 1907 approve bans on the use of poison; poisoned weapon; weapon, ammunition or substances that can inflict unnecessary suffering. After First World War at The Washington Conference 1921-1922 and before its early adjournment they reached an agreement on disarmament, limiting of arms and arms control aimed to stop the naval arms race. The world's leading states of that time, the United States, Britain, France, Italy and Japan, agreed to limit the number and tonnage of their large ships.

Modernity dictates its terms, so UN Security Council Resolution 1540, in 2004, obliges States parties to refrain from providing any support to non-state subjects seeking to acquire weapons of mass destruction. Also, it obliges states to develop national criminal law and expand international cooperation for preventing proliferation of weapons of mass destruction. States parties should implement effective export control and shipment of nuclear, chemical and biology weapons, means of its delivery and derived materials in this regard.

Most countries of the world suffer from the effects of climate change such as floods, fires, droughts, earthquakes and others. Climate change has various consequences, because of that measures to combat this phenomenon should be included to all aspects of public policy, including foreign and security policy, trade and development policy.

Terrorism in all its forms and manifestations poses a direct threat to global peace, stability and prosperity, also to the personal security of the person too. It is regular global threat, which doesn't know the borders, nationality or religion. So, international society should resolve this problem by joint efforts. Directions of world cooperation to fight terrorism focused on raising awareness of the threat, developing opportunities for training and response and also to expand cooperation with partner countries and other international participants. World community answers to these transnational threats with development and implementation of a comprehensive strategy aimed on prevention and fights it; border management and security; and building a modern, democratic and efficient police.

About migration flows we need to understand that migration - is multifaceted term, which includes all kinds of population relocation both - voluntary and forced. Character, structure and way of development of voluntary relocation is affected on by demographic, economic, socio-cultural and psychological 
problems, by the way, forced migration is caused by civil war, political or ethnic persecution, famine or environmental catastrophe. Such relocation of people opens up opportunities and creates new challenges (positive or negative) for both of migrants and host country. Conflicts which are caused by migration between different groups of population can have negative influence not only for coexistence in a certain territory, but also endanger international peace and security, for example, at the new religious community. Unlimited migration can turn ethnic groups into a minority at their own territory, and this phenomenon often causes acts of violence inside of community. As example, rebel movement in the state of Tripura in northeastern India was started as reaction to unlimited migration of the Hindu Bengali population from East Bengal to Tripura (Shanthie Mariet D’Souza, 2012).

\subsection{Collective defense and collective security}

International security consists of collective defense and collective security. For the first time, the idea of collective security arose with the advent of the Deprivation of Nations, which took all of responsibility for providing international security at the Europe and outside it. Main conception of international security includes the principle of indivisibility of the world. So, it means that attack to any of states will be recognized as a violation of worldwide peace and aggression. But unfortunately, given doctrine could not keep Germany from two World Wars.

Security threat of one country is has a significant impact to a level of security in the region and poses a threat to international peace. For the purpose of protection of states from external aggression there is a need to start a modern system of collective defense arose with the help of international organizations. Today there are such regional forms of collective defense as NATO - includes 30 states of European region and USA (NATO, 2021), SEATO - includes USA and 2 European states: Great Britain and France and states of Southeast Asia: Thailand, Philippines, Pakistan and others (Office of the Historian, 2021).

The capabilities and features of collective defense are demonstrated by the North Atlantic Treaty of 1949 (NATO Treaty, Washington Treaty). North Atlantic Treaty is based on principle of collective defense, which stays unique and the main rule which unites States parties binding them to protect each other and creating a spirit of solidarity at the North Atlantic Union.

The peculiarities of collective defense are that an act of aggression against one member state is seen as an attack against all allies. For the first time, NATO applied the principle of collective defense enshrined in Art.5 of the Washington Treaty following the September 11, 2001 terrorist attacks against the United States. Subsequently, NATO has taken collective defense measures several times, for example, in response to the situation in Syria and during the Russian-Ukrainian crisis.

NATO has a unified force that is active in the service on an ongoing basis and contributes to the Alliance's collective defense efforts.

From our point of view one of the arguments to support the model of collective security it's any state at any period of time has limited opportunities regarding own resources and without help from outside of other countries can effectively protect national interests.

Collective security - is mechanism of crisis management that obliges all states to resist aggression collectively, which can be committed by any state against another one. At such situation war or acts of aggression can be treated as violation of international peace and security and collective security - is joint actions of all states, which are aimed at protection of peace. States, which support the idea of collective security, chose the way of creating global system of benefits joint national armed forces against any acts of aggression. Thus, UN General Assembly Resolution 3314 (XXXIX) of December 14, 1974 defines aggression; the need to create a global security system based on international organizations (UN, OSCE, NATO and others) is determined; enhancing the role of the UN Security Council, given that its permanent members must not only be staunch supporters of the ideas of international peace and collective security, but also exclude the possibility of their initiative in the manifestation of aggression.

Collective security also can be considered as a means of deterring aggression as it installs that collective power of all nations will be used to repel acts of aggression or war against any state. Thus, collective security is based on well-known principle "One for all and all for one" - aggression against any member of the international community - is aggression against international peace and security. Therefore, states must act together against every case of aggression or war.

At the Encyclopedia of Modern Ukraine (Riznyk, 2014) collective security is defined as system of enshrined in the UN Charter of international law, which regulates the procedure for collective decisionmaking at the state level on the use of force to maintain or restore international peace and security. 
At the monograph "Ukraine in the system of international security" (Vlasiuk et al., 2009) collective security allocated as a system of joint actions of the states of the world or a certain region to prevent threats to the general peace, suppression of aggression or other disturbances of peace in the world or region.

Therefore, summarizing the above we come to the conclusion that collective security its means aimed at ensuring a stable, non-violent, comprehensive peace. System of collective security guarantees by joint efforts to neutralize any acts of aggression or war against the victim state.

\subsection{Elements of collective security}

Given that international security means maintaining peace and security through joint action, we can define two main elements of collective security: national and collective. Thus, national security as constituent element of collective security and characterized with modern security of any state which inextricably linked with security of other states and nations. Any encroachment on security of state actually threatens to national security of other states. Thus, responsibility for security of victim state also relies on other states. Collective - as a part of conception of international security refers to the method of protection in the situation of war or any aggression against security of every state. According to collective security is expected that the aggressor must resist joint effort of all countries. For this purpose, States parties of program/agreement of collective security can create a joint armed force to repel aggression or end the war.

\subsection{Features of collective security}

Considering phenomenon of collective security, we can highlight its basic features.

Collective security - is one of the effective means of managing the armed forces or anti-crisis management. It strives to preserve international peace with the help of crisis management at the situation of threats to world peace or security.

Collective security admits universal character of aggression. Unfortunately, in today's world it is impossible to preserve the national security of an individual state, therefore, war and aggression cannot be completely excluded from international relations. States join forces to stop acts of aggression. Thus, at the situation of violation of international peace and security at the any part of world all states are obliged to join their powers and resources to take effective action against any aggression and to restore international peace.

Collective security prefers universal or global powers with the participation of all states, to maintain international peace and security. In accordance to these states are ready to defend international peace and security together by means of conducting collective military action against acts of aggression.

Collective security involves the creation of international organization (as example - NATO), under the auspices of which States shall, individually or jointly with other States, take the necessary action to put an end to acts of aggression, including the use of allied forces. Thus, at the 2014 NATO introduced the largest strengthening of collective defense since the end of the Cold War. The reason for this was: Russia's annexation of the southern part of the territory of Ukraine, the Autonomous Republic of Crimea; growing security challenges on several southern continents, including acts of aggression by ISIS and other terrorist groups. For example, the NATO Response Force has been tripled, an extremely rapid response force, the so-called Spearhead Force of 5,000 troops has been set up, and multinational battle groups have been deployed in Estonia, Latvia, Lithuania and Poland (NATO, 2020).

\section{Conclusions}

In our opinion, the pursuit of peace with all peoples and governments and international security is the common goal of all peoples, and it is expedient to ensure it by the collective efforts of all states.

It should be noted that system of collective security is one of effective methods to contain the war. Within this system, each state understands that any aggression against it must be met by the collective use of force by all other states. Thus, collective security can be an effective means of deterring a state that has aggressive intentions.

At the same time collective security can work successfully when system of international relations provided with the following conditions - concluding an agreement on defining aggression; popularizing peaceful ways of resolving conflicts; adherence to a clearly developed mechanism of action aimed at ensuring collective security; strengthening peaceful means of resolving crises and international peacekeeping; creation of permanent international peacekeeping forces; stable and effective ways of socio-economic development of all states.

Thus, collective security is a modern tool of crisis management. The joint activity of states to ensure world peace and security, using the system of collective security to achieve this goal, can save humanity from war and acts of aggression. 


\title{
References:
}

1. Shanthie Mariet D'Souza (2012). Armed Conflicts and Movements for Autonomy in India's Northeast. Retrieved from: https://k23aey35bvmn7alprptz3gcl5a-jj2cvlaia66be-www-degruyter-com.translate.goog/ document/doi/10.1355/97898143 [in English].

2. NATO (2021). What is NATO? Retrieved from: https://www.nato.int/nato-welcome/index.html [in English].

3. Office of the Historian (2021). Southeast Asia Treaty Organization (SEATO), 1954. Milestones in the History of U.S. Foreign Relations. Retrieved from: https://history.state.gov/milestones/1953-1960/seato [in English].

4. Riznyk, S.V. (2014). Kolektyvna bezpeka [Kolektyvna bezpeka]. Entsyklopediia Suchasnoi Ukrainy: elektronna versiia. Retrieved from: http://esu.com.ua/search_articles.php?id=5527 [in Ukrainian].

5. Vlasiuk, O.S. (ed.) (2009). Ukraina u systemi mizhnarodnoi bezpeky: monohrafiia [Ukraine in the system of international security: monograph]. Kyiv: Foliant; Stylos, 572 p. [in Ukrainian]

6. NATO (2020). Zakhody shchodo zmitsnennia kolektyvnoi oborony [Measures to strengthen collective defense]. Retrieved from: https://www.nato.int/cps/uk/natohq/topics_110496.htm [in Ukrainian].

\section{ФЕНОМЕН КОЛЕКТИВНОЇ БЕЗПЕКИ ЯК ЕЛЕМЕНТ МІЖНАРОДНОЇ БЕЗПЕКИ В СИСТЕМІ МІЖНАРОДНИХ ВІДНОСИН}

\author{
Людмила ФІЛЯНІНА, \\ дочент кафедри міжнародного права \\ Університету митної справи та фінансів, \\ кандидат юридичних наук, дочент \\ Filyanina.la@gmail.com \\ orcid.org/0000-0002-8805-5510
}

\begin{abstract}
Міжнародна безпека - ие особливий стан міжнародних відносин, що відображає ступінь забезпеченості наиіональних інтересів усіх суб 'єктів світової політики. Зовнішньополітичні відносини держав трунтуються на дотриманні ними загальновизнаних принципів і норм міжнародного права. Дотримання таких норм забезпечує вирішення суперечливих питань і розбіжностей без застосування сили або погрози силою.

Зазначено, що контроль над озброєнням спрямований на обмеження кількості зброї та регулювання їі використання за допомогою двосторонніх $i$ багатосторонніх договорів та домовленостей. Водночас роззброєння спрямоване на ліквідацію иілих категорій систем зброї. Зауважено, щэо поширення зброї масового знищення представляє серйозну загрозу міжнародній безпеиі.

Метою роботи є дослідження ролі колективної безпеки як елементу міжнародної безпеки в системі міжнародних відносин та ї̈ характерних рис. Дослідження трунтується на роботах учених, які в різні часи вивчали питання, пов'язані із системою колективної безпеки (це, наприклад, В.Г. Буткевич, О.С. Власюк, О.С. Кучик, I.I. Лукашук, С.В. Різник та інші автори).

У статті надано сучасну інтерпретацію змісту міжнародної безпеки, що характеризується певними напрямами, такими як контроль над озброєнням, охорона навколишнього середовища, зменшення кількості та нерозповсюдження зброї масового ураження, боротьба з тероризмом, міграчійні потоки, запобігання етнонаиіональним і конфесійним конфліктам.

Констатовано, що колективна безпека віддає перевагу універсальним чи глобальним силам за участю всіх держав для підтримання міжнародного миру й безпеки, а отже, це заходи, спрямовані на забезпечення стабільного, всеосяжного миру. Відповідно, держави спільно готові захищати міжнародний мир і безпеку шляхом проведення спільних військових дій проти актів агресії. Система колективної безпеки гарантуе спільними зусиллями безпеку шляхом нейтралізації будь-яких актів агресії або запобігання війні щодо держави-жертви.
\end{abstract}

Ключові слова: акт агресії, всесвітній мир та безпека, війна, колективна оборона, національна безпека. 